\title{
Incidence of invasive aspergillosis following remission- induction chemotherapy for acute leukemia: a retrospective cohort study in a single Canadian tertiary care centre
}

\author{
Sapha Barkati MD, Simon F. Dufresne MD, Sylvie Bélanger, Barbara Vadnais MScPharm, Julie Bergeron MD, \\ Annie Claude Labbé MD, Michel Laverdière MD
}

\section{Abstract}

Background: The decision to use universal primary antimould prophylaxis to prevent invasive aspergillosis in patients with acute leukemia depends on the incidence of infection at individual centres. We determined our institution's incidence of invasive aspergillosis among patients who received remission-induction chemotherapy for acute leukemia to evaluate the potential benefits of primary antimould prophylaxis.

Methods: We conducted this retrospective cohort study at a Canadian tertiary care centre. From the central pharmacy registries, we retrieved records for all adult patients for whom remission-induction chemotherapy for acute leukemia was prescribed between 2008 and 2010. We retrieved clinical, microbiologic, pathologic and radiologic data from the patients' medical charts. The primary outcome was a diagnosis of probable or proven invasive aspergillosis up to 180 days after resolution of aplasia.

Results: We retrieved records for 123 patients with acute leukemia. Twenty-two of these patients did not receive the prescribed chemotherapy and were excluded from the analysis. Of the 101 patients included, $77(76.2 \%)$ had acute myeloid leukemia. Overall, 136 courses of chemotherapy were administered, with more than 1 course administered to $26(25.7 \%)$ of the 101 patients. In 9 of the patients (8.9\%; 95\% confidence interval 4.2\%-16.2\%), invasive aspergillosis was diagnosed (3 proven and 6 probable cases) a median of 19 (range 11-34) days after initiation of chemotherapy. In 7 (78\%) of these 9 patients, invasive aspergillosis occurred during the first course of chemotherapy. Three patients died within the first year after diagnosis of invasive aspergillosis.

Interpretation: We found a high incidence (8.9\%) of invasive aspergillosis at our centre. This finding triggered the introduction of targeted antimould prophylaxis for patients with acute leukemia who were undergoing remission-induction chemotherapy.

I nvasive fungal infections contribute substantially to illness and death among patients with hematologic malignancy. ${ }^{1}$ The most commonly diagnosed type of invasive fungal infection has shifted over time from invasive candidiasis to invasive aspergillosis. ${ }^{2}$ This shift has been attributed, in part, to the widespread use of fluconazole prophylaxis. ${ }^{2}$ In fact, recent epidemiologic surveys reported that over $90 \%$ of cases of invasive mould diseases in patients with hematologic malignancy were caused by Aspergillus species. ${ }^{1,3}$ Among hematologic cancers, acute myeloid leukemia carries the highest risk of invasive aspergillosis. ${ }^{1,3-6}$ Moreover, despite the growing antifungal armamentarium and new diagnostic strategies, the aspergillosis-attributable mortality rate remains about $30 \%-40 \%$ in patients with hematologic cancer. ${ }^{3,7}$ These findings emphasize the need to develop efficient strategies to avoid this complication.

In a previous randomized multicentre study, prophylaxis with posaconazole (an extended-spectrum triazole) prevented invasive aspergillosis in patients receiving remission-induction chemotherapy for acute myeloid leukemia or myelodysplastic syndrome. ${ }^{8}$ That study also showed that the use of antifungal prophylaxis was associated with improved overall survival. ${ }^{8}$ More recently, the results of a prospective cohort study showed that the incidence of invasive aspergillosis among patients undergoing their first course of remission-induction chemotherapy for acute myeloid leukemia decreased from $13.4 \%$ to $2.6 \%(p=0.018)$ after introduction of universal

Competing interests: None declared.

This article has been peer reviewed.

Correspondence to: Michel Laverdière, michel.laverdiere@umontreal.ca

CMAJ Open 2014.DOI:10.9778/cmajo.20130062 
posaconazole prophylaxis. ${ }^{9}$ International guidelines now recommend posaconazole as the first-line prophylactic agent in patients with neutropenic acute myeloid leukemia or myelodysplastic syndrome. ${ }^{10,11}$ Fluconazole remains the first-line agent for patients with neutropenia associated with other hematologic malignancies.

The incidence of invasive aspergillosis is influenced by many factors, such as underlying disease, age, type of antifungal prophylaxis used, access to recent diagnostic tools, geoclimatic influences, nosocomial outbreaks and construction activities in and around medical centres. ${ }^{6,12-14}$ Accordingly, the incidence of probable or proven invasive aspergillosis among patients undergoing treatment for acute myeloid leukemia before the introduction of posaconazole prophylaxis was variable, ranging from $1.0 \%$ to $18 \% .^{1,3,7,9,15-25}$ The effectiveness of such prophylaxis depends on the incidence of the targeted disease at individual centres. ${ }^{26}$

Our objective was to retrospectively establish the incidence of invasive aspergillosis at our centre among patients who received remission-induction chemotherapy for acute leukemia to evaluate the potential benefit of primary antimould prophylaxis in high-risk patients with profound neutropenia following intensive chemotherapy.

\section{Methods}

\section{Study population and setting}

The study was approved by the research ethics committee of the Hôpital Maisonneuve-Rosemont.

We conducted this single-centre retrospective cohort study between January 2008 and December 2010. All adult patients ( $\geq 18$ years of age) with acute myeloid leukemia or acute lymphocytic leukemia who were admitted during the study period for remission-induction chemotherapy were eligible. Patients with a positive result on a galactomannan antigen-detection test at the beginning of chemotherapy were excluded. Our institution, a 588-bed tertiary care hospital built in 1953, is an important referral centre for hematology and hematopoietic stem cell transplantation. Remissioninduction chemotherapy is conducted in protected rooms with positive-pressure, high-efficiency particulate air filtration. Fluconazole was the first-line antifungal prophylactic used during the study period. All patients were screened for serum-circulating galactomannan antigen (with Platelia Aspergillus enzyme immunoassay, Bio-Rad Laboratories, Montréal, Quebec) twice weekly from the start of chemotherapy until bone marrow recovery (defined as absolute neutrophil count $>0.5 \times 10^{9} / \mathrm{L}$ for 2 consecutive days). If a patient had a positive result on the galactomannan antigendetection test and/or unexplained and persistent ( $\geq 4$ days) febrile neutropenia refractory to broad-spectrum antibiotics, thoracic computed tomography (CT) was performed, followed by fibreoptic bronchoscopy with bronchoalveolar lavage when clinically indicated. In addition to the usual histopathologic analysis and bacterial, viral and fungal culture, bronchoalveolar lavage fluid was subjected to galactomannan antigen-detection testing.

\section{Data collection}

We retrieved records from the hospital's central pharmacy database registries for remission-induction chemotherapy regimens prescribed during the study period for patients with acute myeloid leukemia or acute lymphocytic leukemia. We performed a retrospective systematic review of patients' medical charts and computerized hospital databases up to 180 days after resolution of aplasia. We did not exclude patients who received posaconazole prophylaxis during remissioninduction chemotherapy (as part of a clinical trial or for other reasons), because our aim was to determine the true incidence of invasive aspergillosis at our centre. We collected data on demographic characteristics, underlying disease, type of remission-induction chemotherapy, duration of neutropenia, administration of antifungals (for prophylaxis or therapy) and diagnostic procedures, along with any relevant microbiologic, pathologic and radiologic data. We included in our analysis any systemic antifungal therapy administered over the period from initiation of remission-induction chemotherapy to resolution of aplasia.

\section{Definitions and data analysis}

We based our definitions of invasive aspergillosis on the 2008 criteria of the European Organisation for Research and Treatment of Cancer/Invasive Fungal Infections Cooperative Group and the National Institute of Allergy and Infectious Diseases Mycoses Study Group.27 Only patients with proven or probable invasive aspergillosis were included in the analysis. Briefly, proven cases of invasive aspergillosis required histopathologic or cytopathologic examination showing hyphae from a biopsy specimen, with evidence of associated tissue damage or a positive culture result for a sample obtained from a normally sterile site. Probable cases required an association of host factors, mycologic results (including but not limited to detection of galactomannan antigen and positive culture result for a sample from a nonsterile site) and clinical criteria. The results of serum galactomannan antigendetection testing were considered positive if 2 consecutive serum samples had optical density of 0.5 or higher. For bronchoalveolar lavage fluids, optical density of 2.0 or higher (cutoff established in a local performance study28) was defined as positive. Data were analyzed with descriptive statistics. Categorical variables are expressed as frequencies and percentages, and non-normally distributed continuous variables are expressed as medians with interquartile ranges (IQRs).

\section{Results}

From the pharmacy registries, we retrieved remission-induction chemotherapy prescriptions for treatment of acute leukemia in 123 patients. Twenty-two of these patients did not undergo their chemotherapy course and were excluded from the analysis (Figure 1). We analyzed data for a total of 136 courses of remission-induction chemotherapy administered to 101 patients over the 3 -year study period (Table 1). The annual number of regimens administered was 40 in both 2008 and 2009 and 56 in 2010. The majority of patients (75 [74.3\%]) 
received only 1 course of chemotherapy; 19 (18.8\%) received 2 courses, and 7 (6.9\%) received more than 2 courses. Acute myeloid leukemia was the most common diagnosis (77 patients [76.2\%]).
During the study period, posaconazole prophylaxis was administered in conjunction with 11 courses of chemotherapy (no courses in 2008, 3 courses in 2009 and 8 courses in 2010). Five patients received posaconazole prophylaxis during their

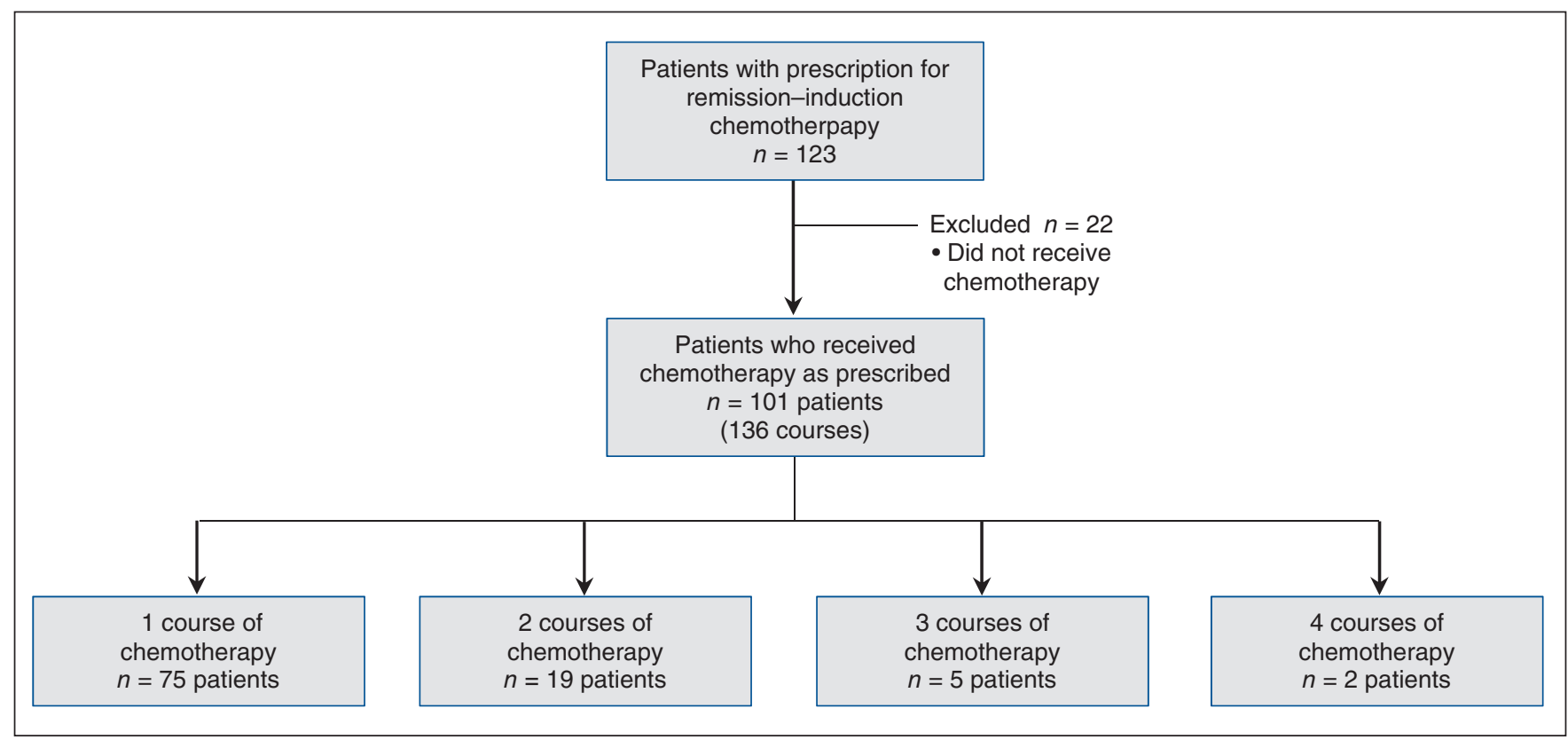

Figure 1: Selection of patients from the hospital's central pharmacy database registries, on the basis of prescriptions for remission-induction chemotherapy for acute leukemia.

Table 1: Clinical characteristics of patients and chemotherapy courses over time

\begin{tabular}{|c|c|c|c|c|}
\hline \multirow[b]{2}{*}{ Characteristic } & \multicolumn{4}{|c|}{ Year; no. of patients* } \\
\hline & 2008 & 2009 & 2010 & All years \\
\hline \multicolumn{5}{|l|}{ No. of patients } \\
\hline Eligible & 43 & 37 & 43 & 123 \\
\hline Did not receive chemotherapy & 8 & 11 & 3 & 22 \\
\hline With evaluable data & 35 & 26 & 40 & 101 \\
\hline Age, yr, median (IQR)† & $50(38.5-59.5)$ & $49(39.0-58.3)$ & $43.5(36.0-60.3)$ & $48(37.0-60.0)$ \\
\hline Sex, male, no. $(\%) \dagger$ & $20(57)$ & $18(69)$ & $21(52)$ & $59(58)$ \\
\hline \multicolumn{5}{|l|}{ Underlying disease $†$} \\
\hline Acute myeloid leukemia & 24 & 21 & 32 & 77 \\
\hline Acute lymphocytic leukemia & 8 & 5 & 7 & 20 \\
\hline Biphenotypical acute leukemia & 3 & 0 & 1 & 4 \\
\hline Total & 35 & 26 & 40 & 101 \\
\hline \multicolumn{5}{|l|}{$\begin{array}{l}\text { Courses of remission-induction } \\
\text { chemotherapy }\end{array}$} \\
\hline 1 course & 31 & 17 & 27 & 75 \\
\hline 2 courses & 3 & 6 & 10 & 19 \\
\hline 3 courses & 1 & 1 & 3 & 5 \\
\hline 4 courses & 0 & 2 & 0 & 2 \\
\hline Total no. of courses & 40 & 40 & 56 & 136 \\
\hline $\begin{array}{l}\text { Note: IQR = interquartile range. } \\
\text { *Except where otherwise indicated. } \\
\text { †For patients with evaluable data. }\end{array}$ & & & & \\
\hline
\end{tabular}


first course of remission-induction chemotherapy, usually as part of a clinical trial (4 patients). Fluconazole prophylaxis was prescribed in conjunction with a total of 109 courses $(80.1 \%)$. Patients were exposed to a wide range of systemic antifungal agents during the period of aplasia, as detailed in Table 2 .

A total of 9 cases of invasive aspergillosis ( 3 proven and 6 probable) were diagnosed over the 3 -year study period, for a calculated cumulative incidence of $8.9 \%$ (95\% confidence interval $[\mathrm{CI}] 4.2 \%-16.2 \%)$. The incidence increased to $10.0 \%$ (95\% CI $4.7 \%-18.1 \%$ ) when the 11 patients who received posaconazole prophylaxis were excluded from the analysis. Table 3 details the clinical characteristics of the 9 proven and probable cases of invasive aspergillosis. Pulmonary disease was observed in all 9 patients, 8 of whom underwent fibreoptic bronchoscopy with bronchoalveolar lavage. One patient, a 66year-old woman (patient 1), experienced disseminated infection with positive histopathologic f indings and growth of Aspergillus fumigatus complex in skin lesions. The median age at diagnosis was 57 (IQR 53-58) years, and the ratio of men to women was 4:5. In 7 cases (78\%), invasive aspergillosis occurred after the first course of remission-induction chemotherapy, and the remaining 2 cases $(22 \%)$ were diagnosed during the second course of chemotherapy. Acute myeloid leukemia was the underlying hematologic malignancy in 7 patients (78\%). Invasive aspergillosis was diagnosed at a median of 19 (range 11-34) days after initiation of chemotherapy. The lowest absolute neutrophil count was $0 \times 10^{9} / \mathrm{L}$ in all but 1 patient; the exception was a patient with acute lymphocytic leukemia who never
Table 2: Systemic antifungal treatment (prophylactic and therapeutic)

\begin{tabular}{|c|c|}
\hline Antifungal agent & $\begin{array}{c}\text { No. }(\%) \text { of courses } \\
\text { of chemotherapy } \\
n=136\end{array}$ \\
\hline \multicolumn{2}{|l|}{ Monotherapy } \\
\hline Fluconazole & $37(27.2)$ \\
\hline Echinocandin* & $9(6.6)$ \\
\hline Antifungal azole & $5 \quad(3.7) \dagger$ \\
\hline Amphotericin B & $0 \quad(0)$ \\
\hline \multicolumn{2}{|l|}{ Combination therapy } \\
\hline Fluconazole + echinocandin & $46(33.8)$ \\
\hline $\begin{array}{l}\text { Fluconazole }+ \text { echinocandin }+ \\
\text { antifungal azole }\end{array}$ & $17(12.5) \ddagger$ \\
\hline Echinocandin + antifungal azole & $10(7.4)$ \\
\hline Other combinations§ & $12(8.8)$ \\
\hline \multicolumn{2}{|c|}{$\begin{array}{l}\text { *Echinocandin consisted of caspofungin and/or micafungin. } \\
\text { tPosaconazole for } 4 \text { courses of chemotherapy and voriconazole for } 1 \text { course. } \\
\text { †The antifungal azole was posaconazole for } 8 \text { courses of chemotherapy, } \\
\text { voriconazole for } 8 \text { courses, and both posaconazole and voriconazole for } \\
1 \text { course (total } 17 \text { courses). } \\
\text { §Fluconazole }+ \text { antifungal azoles ( } n=3 \text { courses), fluconazole }+ \text { caspofungin } \\
+ \text { amphotericin B }(n=1 \text { course), fluconazole }+ \text { antifungal azole }+ \text { amphotericin B } \\
\text { ( } n=2 \text { courses), fluconazole }+ \text { caspofungin }+ \text { antifungal azole }+ \text { amphotericin B } \\
\text { ( } n=3 \text { courses), caspofungin }+ \text { antifungal azole }+ \text { amphotericin B }(n= \\
2 \text { courses), antifungal azole }+ \text { amphotericin B }(n=1 \text { course). }\end{array}$} \\
\hline
\end{tabular}

Table 3: Characteristics of patients with proven or probable invasive aspergillosis

\begin{tabular}{|c|c|c|c|c|c|c|c|c|c|c|c|c|}
\hline $\begin{array}{l}\text { Patient } \\
\text { no. }\end{array}$ & Year & Sex & $\begin{array}{l}\text { Age, } \\
\text { yr }\end{array}$ & Diagnosis & $\begin{array}{c}\text { Course of } \\
\text { occurrence* }\end{array}$ & $\begin{array}{c}\text { Interval to } \\
\text { diagnosis, } \\
\text { d† }\end{array}$ & $\begin{array}{l}\text { Nadir } \\
\text { ANC, } \\
\times 10^{9} / \mathrm{L}\end{array}$ & $\begin{array}{l}\text { Biopsy } \\
\text { sitef }\end{array}$ & $\begin{array}{l}\text { Galactomannan } \\
\text { antigen test, } \\
\text { index value§ }\end{array}$ & $\begin{array}{l}\text { Organism } \\
\text { cultured }\end{array}$ & PPx & Outcome \\
\hline \multicolumn{13}{|l|}{ Proven } \\
\hline 1 & 2008 & $\mathrm{~F}$ & 66 & AML & 1 & 19 & 0 & Skin & Serum: > 6.4 & $\begin{array}{l}\text { Aspergillus } \\
\text { fumigatus }\end{array}$ & $\mathrm{FI}$ & Died \\
\hline 2 & 2009 & $\mathrm{M}$ & 53 & AML & 1 & 19 & 0 & Lung & $\begin{array}{l}\text { Serum: } 3.0 \\
\text { Lavage: } 3.0\end{array}$ & $\begin{array}{l}\text { Aspergillus } \\
\text { terreus }\end{array}$ & $\mathrm{FI}$ & Died \\
\hline 3 & 2010 & $\mathrm{~F}$ & 57 & ALL & 2 & 11 & 1.4 & Lung & $\begin{array}{l}\text { Serum: }<0.5 \\
\text { Lavage: }<2.0\end{array}$ & No growth & C & Survived \\
\hline \multicolumn{13}{|c|}{ Probable } \\
\hline 4 & 2009 & $\mathrm{M}$ & 56 & AML & 1 & 11 & 0 & NA & $\begin{array}{l}\text { Serum: }<0.5 \\
\text { Lavage: } 3.5\end{array}$ & No growth & $\mathrm{FI}$ & Died \\
\hline 5 & 2009 & $\mathrm{~F}$ & 40 & ALL & 2 & 28 & 0 & NA & $\begin{array}{l}\text { Serum: }<0.5 \\
\text { Lavage: } 6.9\end{array}$ & $\begin{array}{l}\text { Aspergillus } \\
\text { sp. }\end{array}$ & C & Survived \\
\hline 6 & 2009 & $M$ & 57 & AML & 1 & 24 & 0 & NA & $\begin{array}{l}\text { Serum: }<0.5 \\
\text { Lavage: } 5.8\end{array}$ & $\begin{array}{l}\text { Aspergillus } \\
\text { nidulans }\end{array}$ & C & Survived \\
\hline 7 & 2010 & $M$ & 38 & AML & 1 & 19 & 0 & NA & $\begin{array}{l}\text { Serum: }<0.5 \\
\text { Lavage: } 4.9\end{array}$ & No growth & $\mathrm{FI}$ & Survived \\
\hline 8 & 2010 & $\mathrm{~F}$ & 65 & AML & 1 & 17 & 0 & NA & $\begin{array}{l}\text { Serum: } 4.4 \\
\text { Lavage: }<2.0\end{array}$ & No growth & $\mathrm{FI}$ & Died \\
\hline 9 & 2010 & $\mathrm{~F}$ & 58 & AML & 1 & 34 & 0 & NA & $\begin{array}{l}\text { Serum: } 5.9 \\
\text { Lavage: } 3.0\end{array}$ & No growth & $\mathrm{FI}$ & Survived \\
\hline \multicolumn{13}{|c|}{$\begin{array}{l}\text { Note: } A L L=\text { acute lymphocytic leukemia, } A M L=\text { acute myeloid leukemia, } A N C=\text { absolute neutrophil count, } \mathrm{C}=\text { caspofungin, } \mathrm{FI}=\text { fluconazole, } \mathrm{NA}=\text { not applicable, } \mathrm{PPx}= \\
\text { prophylaxis. } \\
\text { *Course of remission-induction chemotherapy during which invasive aspergillosis occurred. } \\
\text { †Number of days from initiation of chemotherapy until diagnosis of invasive aspergillosis. } \\
\text { †Histopathology results compatible with invasive aspergillosis (hyphae-associated tissue damage). } \\
\text { §Index value refers to optical density. "Lavage" refers to fluid from bronchoalveolar lavage. Values }<0.5 \text { for serum and }<2.0 \text { for lavage fluid are considered negative. }\end{array}$} \\
\hline
\end{tabular}


experienced neutropenia. The median duration of neutropenia was 18 (IQR 13-22) days. Three patients received caspofungin prophylaxis, and the other 6 patients received fluconazole prophylaxis. Aspergillus species were cultured in samples from 4 of the 9 patients. The galactomannan antigen was detected in 8 patients: in bronchoalveolar lavage fluids only $(n=4)$, serum only $(n=2)$ or both $(n=2)$. Detection of galactomannan antigen was the only positive mycologic criterion identified in 4 of the 6 patients with probable invasive aspergillosis.

A total of 4 patients died, 2 with proven and 2 with probable invasive aspergillosis. Three of the patients died within 1 year of the diagnosis of invasive aspergillosis. Only 1 death was directly attributable to invasive aspergillosis (patient 1).

\section{Interpretation}

In this study, we sought to determine the incidence of invasive aspergillosis among adult patients who underwent remissioninduction chemotherapy for acute leukemia in a Canadian tertiary care centre.

We identified 9 cases of proven or probable invasive aspergillosis following remission-induction chemotherapy during the 3-year study period. One case occurred in 2008, and the other 8 cases were divided evenly between 2009 and 2010, which suggests the absence of an outbreak. No seasonal variation or notable temporal trends were observed. There were no major construction activities around the institution during the study period, and none of the interior renovation projects that took place during these targeted years were located close to the hematology units. Moreover, courses of remission-induction chemotherapy for patients with acute leukemia were administered in individual rooms with positivepressure high-efficiency particulate air filtration. However, even in this setting with low environmental risk, the cumulative incidence of invasive aspergillosis among patients with acute leukemia was $8.9 \%$ (95\% CI $4.2 \%-16.2 \%$ ), higher than some of the values reported in recent studies (Table 4). In fact, the incidence of invasive aspergillosis has been highly variable across studies, a reflection of the multiple risk factors that determine its occurrence. ${ }^{2,6,12,13,31}$ For purposes of homogeneity, we excluded from Table 4 any studies that clearly described universal use of posaconazole as first-line prophylaxis. Important heterogeneity among studies dictates caution when generalizing results from one institution to another.

As expected, most cases of invasive aspergillosis in this study (7 of 9 patients [78\%]) occurred during the first course of remission-induction chemotherapy, which is considered the highest-risk period for development of invasive fungal disease among patients with acute leukemia. ${ }^{1,18,25,32}$ Our study included 10 patients with acute promyelocytic leukemia, all of whom were treated with an all-trans-retinoic acid regimen. All-transretinoic acid is metabolized by cytochrome $\mathrm{P} 450$ isoenzymes, including CYP2C9 and CYP3A4. Possible interactions between this agent and fluconazole (CYP2C9 inhibitor), voriconazole (CYP2C9/3A4 inhibitor) and posaconazole (CYP3A4 inhibitor) have been reported, ${ }^{33-37}$ but we did not observe any interactions of this type in our patients. The aspergillosis-attributable mor- tality rate in our study was $11 \%$ (1 of 9 patients). Three other patients with acute myeloid leukemia died within 2 years after diagnosis of invasive aspergillosis, for a 2-year global mortality rate of $44 \%$ (4 of 9 patients). A recent study reported that the 2 -year survival rate among patients with acute myeloid leukemia and invasive aspergillosis was significantly lower than among patients without invasive aspergillosis, even when the rate was adjusted for response to induction chemotherapy. ${ }^{38}$

The galactomannan antigen-detection test, in combination with CT of the lung, is an important tool for early recognition of pulmonary aspergillosis, ${ }^{39}$ and the performance of galactomannan antigen-detection testing in serum has been studied extensively. ${ }^{40,41}$ However, among the patients in our study, serum galactomannan antigen-detection testing had limited performance. If diagnosis had been based solely on the results of this test, 5 cases of invasive aspergillosis would have been missed. Interestingly, 3 of these 5 patients were receiving caspofungin therapy. Marr and others ${ }^{42}$ reported a significant decrease in the sensitivity of galactomannan antigen-detection testing when patients were receiving mould-active antifungal treatment. In our study, bronchoalveolar lavage fluid was more useful than serum for diagnostic assay of galactomannan antigen.

Following the randomized controlled trial by Cornely and colleagues in $2007,{ }^{8}$ subsequent studies showed, in real-life settings, that the incidence of invasive aspergillosis among patients with acute myeloid and lymphocytic leukemia declined after introduction of posaconazole prophylaxis., ${ }^{9,45}$ Cornely and colleagues $^{8}$ reported a $1 \%$ incidence of breakthrough invasive aspergillosis among patients with acute myeloid leukemia who received posaconazole prophylaxis, with a relative risk reduction of 0.9. Given the overall incidence of invasive aspergillosis at our centre $(8.9 \%)$ and the theoretical relative risk reduction with posaconazole prophylaxis $(0.9)$, the number needed to treat to prevent 1 case of invasive aspergillosis is 13 patients.

The burden of invasive aspergillosis, in terms of mortality, morbidity and cost, and the high incidence at our institution prompted us to consider using posaconazole prophylaxis in this high-risk population. Using data from the study by Cornely and colleagues, ${ }^{8}$ subsequent researchers have conducted cost-effectiveness analyses of posaconazole prophylaxis. ${ }^{46-48}$ Two of these studies, which were conducted from the perspective of provincial health care systems in Canada, showed that posaconazole prophylaxis was cost-effective. ${ }^{47,48}$ Taking into account these cost-effectiveness analyses and our institution's high incidence of invasive aspergillosis, it appeared reasonable to initiate use of posaconazole prophylaxis as a standard of care for patients with acute myeloid leukemia undergoing remission-induction chemotherapy.

\section{Limitations}

Our study had several limitations. First, many of the patients were exposed to 1 or more mould-active antifungal therapies during the period of aplasia. However, because we sought to determine the incidence of invasive aspergillosis in a real-life setting, we did not exclude patients on the basis of exposure to these drugs. Interestingly, proven or probable invasive aspergillosis was not diagnosed in any of the patients who 
received posaconazole prophylaxis. Second, because the data were collected retrospectively, it was difficult to establish, at least for some patients, the clinical indications for antifungal treatment (prophylactic v. empiric) and to confirm that the patients actually received the prescribed medication. Third, we did not determine risk factors for invasive aspergillosis in this population because the small sample size would have impaired the validity of the results. Finally, we conducted our study at a single tertiary care institution, a referral centre for hematology and hematopoietic stem cell transplantation. As such, and given that the incidence of invasive aspergillosis is influenced by many factors, generalizability may be limited.

\section{Conclusion}

We determined that the incidence of invasive aspergillosis among adult patients who underwent intensive remission-induction chemotherapy for acute leukemia at our institution was $8.9 \%$
(95\% CI $4.2 \%-16.2 \%)$. The number needed to treat to prevent 1 case of invasive aspergillosis would be about 13 patients. These findings triggered the initiation, in 2011, of universal posaconazole prophylaxis for patients with acute myeloid leukemia undergoing remission-induction chemotherapy at our institution. However, many issues remain unresolved regarding this form of prophylaxis, including the performance of serum galactomannan antigen-detection testing and thoracic CT in low-prevalence populations, the impact of chemotherapy-induced gastrointestinal tract disturbances on bioavailability of posaconazole, the need to monitor serum concentration of posaconazole, the indication for empiric antifungal treatment in febrile neutropenia and the treatment of breakthrough invasive aspergillosis in patients who are receiving posaconazole prophylaxis. Prospective surveillance for invasive aspergillosis in patients with acute myeloid leukemia following introduction of universal posaconazole prophylaxis may shed light on some of these issues.

Table 4: Reported incidence of proven or probable invasive aspergillosis in adult patients with acute leukemia*

\begin{tabular}{|c|c|c|c|c|c|c|c|}
\hline Reference & $\begin{array}{l}\text { Surveillance } \\
\text { period }\end{array}$ & Study design & Country & $\begin{array}{c}\text { Hematologic } \\
\text { malignancy }\end{array}$ & $\begin{array}{l}\text { No. of } \\
\text { patients }\end{array}$ & $\begin{array}{c}\text { Incidence, } \\
\%\end{array}$ & $\begin{array}{l}\text { Standardized } \\
\text { definitions }\end{array}$ \\
\hline Klimowski et al. ${ }^{21}$ & $1964-1983$ & Single centre & USA & $\begin{array}{l}\text { AML } \\
\text { ALL }\end{array}$ & $\begin{array}{l}716 \\
546\end{array}$ & $\begin{array}{l}6.7 \\
3.3\end{array}$ & NA \\
\hline Pagano et al. ${ }^{18}$ & $1987-1998$ & $\begin{array}{l}\text { Multicentre, } \\
\text { retrospective }\end{array}$ & Italy & $\mathrm{AL}$ & 4448 & $6.2 \dagger$ & MSG $^{29}$ \\
\hline Nosari et al. ${ }^{22}$ & 1989-1999 & $\begin{array}{l}\text { Single centre, } \\
\text { retrospective }\end{array}$ & Italy & $A L$ & 675 & 7.1 & NA \\
\hline Cornet et al. ${ }^{20}$ & 1994-1999 & $\begin{array}{l}\text { Multicentre, } \\
\text { prospective }\end{array}$ & France & $\begin{array}{l}\text { AML } \\
\text { ALL }\end{array}$ & NA & $\begin{array}{l}8.0 \\
6.3\end{array}$ & 2002 EORTC/MSG ${ }^{30}$ \\
\hline Mühlemann et al. ${ }^{25}$ & 1995-1999 & $\begin{array}{l}\text { Single centre, } \\
\text { retrospective }\end{array}$ & Switzerland & $\begin{array}{c}\mathrm{AL} \\
\mathrm{MDS}\end{array}$ & 101 & 12 & 2002 EORTC/MSG ${ }^{30}$ \\
\hline Caira et al. ${ }^{3}$ & 1999-2003 & $\begin{array}{l}\text { Multicentre, } \\
\text { prospective }\end{array}$ & Italy & AML & 1596 & 10.5 & 2002 EORTC/MSG ${ }^{30}$ \\
\hline Pagano et al. ${ }^{1}$ & 1999-2003 & $\begin{array}{l}\text { Multicentre, } \\
\text { retrospective }\end{array}$ & Italy & $\begin{array}{c}\text { AL } \\
\text { AML } \\
\text { ALL }\end{array}$ & $\begin{array}{l}4185 \\
3012 \\
1173\end{array}$ & $\begin{array}{l}6.1 \\
7.1 \\
3.8\end{array}$ & 2002 EORTC/MSG ${ }^{30}$ \\
\hline Slobbe et al. ${ }^{15}$ & $2002-2007$ & $\begin{array}{l}\text { Single centre, } \\
\text { prospective }\end{array}$ & Netherlands & $\begin{array}{l}\text { AML } \\
\text { MDS }\end{array}$ & 269 & 18 & 2008 EORTC/MSG ${ }^{27}$ \\
\hline Vehreschild et al. ${ }^{9}$ & $2003-2005$ & $\begin{array}{l}\text { Multicentre, } \\
\text { prospective }\end{array}$ & Germany & AML & 82 & 13.4 & 2002 EORTC/MSG ${ }^{30}$ \\
\hline Nicolle et al. ${ }^{23} \ddagger$ & 2004-2009 & $\begin{array}{l}\text { Single centre, } \\
\text { prospective }\end{array}$ & France & $\begin{array}{c}\mathrm{AL} \\
\mathrm{AML} \\
\mathrm{ALL}\end{array}$ & $\begin{array}{r}2928 \\
2078 \\
850\end{array}$ & $\begin{array}{l}3.8 \\
4.4 \\
2.2\end{array}$ & 2008 EORTC/MSG ${ }^{27}$ \\
\hline Montagna et al. ${ }^{17}$ & $2007-2008$ & $\begin{array}{l}\text { Multicentre, } \\
\text { prospective }\end{array}$ & Italy & $\begin{array}{c}\text { AL } \\
A M L \\
A L L\end{array}$ & $\begin{array}{r}243 \\
195 \\
48\end{array}$ & $\begin{array}{l}1.2 \\
1.0 \\
2.1\end{array}$ & 2008 EORTC/MSG ${ }^{27}$ \\
\hline Pagano et al. ${ }^{19}$ & $2007-2009$ & $\begin{array}{l}\text { Multicentre, } \\
\text { prospective }\end{array}$ & Italy & AML & 747 & 4.2 & NA \\
\hline Nucci et al. ${ }^{24}$ & $2007-2009$ & $\begin{array}{l}\text { Multicentre, } \\
\text { prospective }\end{array}$ & Brazil & $\begin{array}{l}\text { AML } \\
\text { MDS }\end{array}$ & 202 & 5.9 & 2008 EORTC/MSG ${ }^{27}$ \\
\hline $\begin{array}{l}\text { Barkati et al. } \\
\text { (present study) }\end{array}$ & 2008-2010 & $\begin{array}{l}\text { Single centre, } \\
\text { retrospective }\end{array}$ & Canada & $\mathrm{AL}$ & 101 & 8.9 & 2008 EORTC/MSG ${ }^{27}$ \\
\hline \multicolumn{8}{|c|}{$\begin{array}{l}\text { Note: } \mathrm{AL}=\text { acute leukemia, } \mathrm{ALL}=\text { acute lymphocytic leukemia, } \mathrm{AML}=\text { acute myeloid leukemia, EORTC/MSG = European Organisation for Research and Treatment of } \\
\text { Cancer/Invasive Fungal Infections Cooperative Group and Mycoses Study Group of the National Institute of Allergy and Infectious Diseases, MDS = myelodysplastic } \\
\text { syndrome, MSG = Mycoses Study Group of the National Institute of Allergy and Infectious Diseases, NA = not available. } \\
\text { *Patients with invasive aspergillosis following hematopoietic stem cell transplant for acute leukemia were excluded from this review. } \\
\text { tlncidence for all cases of filamentous fungal infection (76\% of which were invasive aspergillosis). } \\
\text { fPosaconazole prophylaxis was introduced in remission-induction chemotherapy for patients with AML during the year } 2007 .\end{array}$} \\
\hline
\end{tabular}




\section{References}

1. Pagano L, Caira M, Candoni A, et al. The epidemiology of fungal infections in patients with hematologic malignancies: the SEIFEM-2004 study. Haematologica 2006;91:1068-75

2. Leventakos K, Lewis RE, Kontoyiannis DP. Fungal infections in leukemia patients: How do we prevent and treat them? Clin Infect Dis 2010;50:405-15.

3. Caira M, Girmenia C, Fadda RM, et al. Invasive fungal infections in patients with acute myeloid leukemia and in those submitted to allogeneic hemopoietic stem cell transplant: Who is at highest risk? Eur 7 Haematol 2008;81:242-3.

4. Pagano L, Caira M, Picardi M, et al. Invasive aspergillosis in patients with acute leukemia: update on morbidity and mortality-SEIFEM-C Report. Clin Infect Dis 2007;44:1524-5.

5. Perkhofer S, Lass-Florl C, Hell M, et al. The Nationwide Austrian Aspergillus Registry: a prospective data collection on epidemiology, therapy and outcome of invasive mould infections in immunocompromised and/or immunosuppressed patients. Int 7 Antimicrob Agents 2010;36:531-6.

6. Caira M, Mancinelli M, Leone G, et al. Invasive aspergillosis in acute leukemias: old and new risk factors and epidemiological trends. Med Mycol 2011;49 Suppl 1: S13-6.

7. Pagano L, Caira M, Candoni A, et al. Invasive aspergillosis in patients with acute myeloid leukemia: a SEIFEM-2008 registry study. Haematologica 2010; 95:644-50.

8. Cornely OA, Maertens J, Winston DJ, et al. Posaconazole vs. fluconazole or itraconazole prophylaxis in patients with neutropenia. N Engl 7 Med 2007; 356:348-59.

9. Vehreschild JJ, Ruping MJ, Wisplinghoff $\mathrm{H}$, et al. Clinical effectiveness of posaconazole prophylaxis in patients with acute myelogenous leukaemia (AML): a 6 year experience of the Cologne AML cohort. 7 Antimicrob Chemother 2010;65:1466-71.

10. Walsh TJ, Anaissie EJ, Denning DW, et al. Treatment of aspergillosis: clinical practice guidelines of the Infectious Diseases Society of America. Clin Infect Dis 2008;46:327-60.

11. Baden LR, Bensinger $W$, Angarone $M$, et al. Prevention and treatment of cancerrelated infections. 7 Natl Compr Canc Netw 2012;10:1412-45.

12. Karthaus M. Prophylaxis and treatment of invasive aspergillosis with voriconazole, posaconazole and caspofungin: review of the literature. Eur 7 Med Res 2011;16:145-52.

13. Maertens J. Evaluating prophylaxis of invasive fungal infections in patients with haematologic malignancies. Eur 7 Haematol 2007;78:275-82

14. Panackal AA, Li H, Kontoyiannis DP, et al. Geoclimatic influences on invasive aspergillosis after hematopoietic stem cell transplantation. Clin Infect Dis 2010; 50:1588-97.

15. Slobbe L, Polinder S, Doorduijn JK, et al. Outcome and medical costs of patients with invasive aspergillosis and acute myelogenous leukemia-myelodysplastic syndrome treated with intensive chemotherapy: an observational study. Clin Infect Dis 2008;47:1507-12.

16. Fisher BD, Armstrong D, Yu B, et al. Invasive aspergillosis. Progress in early diagnosis and treatment. Am 7 Med 1981;71:571-7.

17. Montagna MT, De Giglio O, Napoli C, et al. Invasive fungal infections in patients with hematologic malignancies (aurora project): lights and shadows during 18-months surveillance. Int 7 Mol Sci 2012;13:774-87.

18. Pagano L, Girmenia C, Mele L, et al. Infections caused by filamentous fungi in patients with hematologic malignancies. A report of 391 cases by GIMEMA Infection Program. Haematologica 2001;86:862-70.

19. Pagano L, Caira M, Nosari A, et al. Etiology of febrile episodes in patients with acute myeloid leukemia: results from the Hema e-Chart Registry. Arch Intern Med 2011;171:1502-3.

20. Cornet M, Fleury L, Maslo C, et al. Epidemiology of invasive aspergillosis in France: a six-year multicentric survey in the Greater Paris area. 7 Hosp Infect 2002;51:288-96.

21. Klimowski LL, Rotstein C, Cummings KM. Incidence of nosocomial aspergillosis in patients with leukemia over a twenty-year period. Infect Control Hosp Epidemiol 1989;10:299-305.

22. Nosari A, Oreste P, Cairoli R, et al. Invasive aspergillosis in haematological malignancies: clinical findings and management for intensive chemotherapy completion. Am 7 Hematol 2001;68:231-6.

23. Nicolle MC, Bénet T, Thiebaut A, et al. Invasive aspergillosis in patients with hematologic malignancies: incidence and description of 127 cases enrolled in a single institution prospective survey from 2004 to 2009. Haematologica 2011; 96:1685-91.

24. Nucci M, Garnica M, Gloria AB, et al. Invasive fungal diseases in haematopoietic cell transplant recipients and in patients with acute myeloid leukaemia or myelodysplasia in Brazil. Clin Microbiol Infect 2013;19:745-51.

25. Mühlemann K, Wenger C, Zenhausern R, et al. Risk factors for invasive aspergillosis in neutropenic patients with hematologic malignancies. Leukemia $2005 ; 19: 545-50$

26. De Pauw BE, Donnelly JP. Prophylaxis and aspergillosis-Has the principle been proven? N Engl 7 Med 2007;356:409-11.

27. De Pauw B, Walsh TJ, Donnelly JP, et al. Revised definitions of invasive fungal disease from the European Organization for Research and Treatment of Cancer/
Invasive Fungal Infections Cooperative Group and the National Institute of Allergy and Infectious Diseases Mycoses Study Group (EORTC/MSG) Consensus Group. Clin Infect Dis 2008;46:1813-21

28. Luong ML, Filion C, Labbe AC, et al. Clinical utility and prognostic value of bronchoalveolar lavage galactomannan in patients with hematologic malignancies. Diagn Microbiol Infect Dis 2010;68:132-9.

29. Denning DW, Lee JY, Hostetler JS, et al. NIAID Mycoses Study Group multicenter trial of oral itraconazole therapy for invaisve aspergillosis. $\mathrm{Am} 7 \mathrm{Med}$ 1994;97:135-44.

30. Ascioglu S, Rex JH, de Pauw B, et al.; Invasive Fungal Infections Cooperative Group of the European Organization for Research and Treatment of Cancer; Mycoses Study Group of the National Institute of Allergy and Infectious Diseases. Defining opportunistic invasive fungal infections in immunocompromised patients with cancer and hematopoietic stem cell transplants: an international consensus. Clin Infect Dis 2002;34:7-14

31. Michallet M, Sobh M, Morisset S, et al. Risk factors for invasive aspergillosis in acute myeloid leukemia patients prophylactically treated with posaconazole. Med Mycol 2011;49:681-7.

32. Denning DW. Invasive aspergillosis. Clin Infect Dis 1998;26:781-803; quiz 804-5.

33. Dixon KS, Hassoun A. Pseudotumor cerebri due to the potentiation of all-trans retinoic acid by voriconazole. 7 Am Pharm Assoc 2010;50:742-4.

34. Mas Morey P, Nigorra Caro M, Cladera Serra A, et al. Possible fulminant toxicity by all-trans-retinoic acid in a patient with acute promyelocytic leukemia. Farm Hosp 2011;35:44-5.

35. Schwartz EL, Hallam S, Gallagher RE, et al. Inhibition of all-trans-retinoic acid metabolism by fluconazole in vitro and in patients with acute promyelocytic leukemia. Biochem Pharmacol 1995;50:923-8.

36. Vanier KL, Mattiussi AJ, Johnston DL. Interaction of all-trans-retinoic acid with fluconazole in acute promyelocytic leukemia. 7 Pediatr Hematol Oncol 2003;25:403-4.

37. Marill J, Cresteil T, Lanotte $M$, et al. Identification of human cytochrome $\mathrm{P} 450$ s involved in the formation of all-trans-retinoic acid principal metabolites. Mol Pharmacol 2000;58:1341-8.

38. Michallet M, Bénet T, Sobh M, et al. Invasive aspergillosis: an important risk factor on the short- and long-term survival of acute myeloid leukemia (AML) patients. Eur 7 Clin Microbiol Infect Dis 2012;31:991-7.

39. Maertens J, Theunissen K, Verhoef G, et al. Galactomannan and computed tomography-based preemptive antifungal therapy in neutropenic patients at high risk for invasive fungal infection: a prospective feasibility study. Clin Infect Dis 2005;41:1242-50.

40. Leeflang MM, Debets-Ossenkopp YJ, Visser CE, et al. Galactomannan detection for invasive aspergillosis in immunocompromized patients. Cocbrane Database Syst Rev 2008;(4):CD007394.

41. Pfeiffer CD, Fine JP, Safdar N. Diagnosis of invasive aspergillosis using a galactomannan assay: a meta-analysis. Clin Infect Dis 2006;42:1417-27.

42. Marr KA, Laverdiere M, Gugel A, et al. Antifungal therapy decreases sensitivity of the Aspergillus galactomannan enzyme immunoassay. Clin Infect Dis 2005; 40:1762-9.

43. Girmenia C, Frustaci AM, Gentile G, et al. Posaconazole prophylaxis during front-line chemotherapy of acute myeloid leukemia: a single-center, real-life experience. Haematologica 2012;97:560-7.

44. Egerer G, Geist MJ. Posaconazole prophylaxis in patients with acute myelogenous leukaemia—results from an observational study. Mycoses 2011;54 Suppl 1:7-11.

45. Illmer T, Babatz J, Pursche S, et al. Posaconazole prophylaxis during induction therapy of patients with acute lymphoblastic leukaemia. Mycoses 2011;54:e143-7.

46. Luong ML, Husain S, Rotstein C. Pharmacoeconomic assessment of therapy for invasive aspergillosis. Mycoses 2013;56:338-49.

47. Dranitsaris G, Khoury H. Posaconazole versus fluconazole or itraconazole for prevention of invasive fungal infections in patients undergoing intensive cytotoxic therapy for acute myeloid leukemia or myelodysplasia: a cost effectiveness analysis. Support Care Cancer 2011;19:1807-13

48. Tahami Monfared AA, O'Sullivan AK, Rotstein C, et al. Economic evaluation of posaconazole versus standard azole therapy as prophylaxis against invasive fungal infections in patients with prolonged neutropenia in Canada. Can 7 Infect Dis Med Microbiol 2012;23:59-64.

Affiliations: Department of Microbiology and Immunology (Barkati, Dufresne, Labbé, Laverdière), Faculty of Medicine, Université de Montréal; Department of Microbiology and Infectious Diseases (Dufresne, Bélanger, Labbé, Laverdière), Department of Pharmacy (Vadnais) Hôpital Maisonneuve-Rosemont; Faculty of Pharmacy (Vadnais), Université de Montréal; Department of Hematology (Bergeron), Hôpital Maisonneuve-Rosemont; Department of Hematology (Beregeron), Faculty of Medicine, Université de Montréal, Montréal, Que.

Contributors: Sapha Barkati contributed to acquisition, analysis and interpretation of the data and also drafted the article. Simon Dufresne contributed to analysis and interpretation of the data and revised the article critically for important intellectual content. Sylvie Bélanger contributed to 
acquisition of the data and revised the article critically for important intellectual content. Barbara Vadnais contributed to study conception and design and to acquisition of the data, and revised the article critically for important intellectual content. Julie Bergeron contributed to study conception and design and revised the article critically for important intellectual content. Annie-Claude Labbé contributed to analysis and interpretation of the data and revised the article critically for important intellectual content. Michel Laverdière contributed to study conception and design and to analysis and interpretation of the data, and revised the article critically for important intellectual content. All authors gave final approval of the version to be published and agree to act as guarantors of the work.

Competing interests: Simon Dufresne has received consultancy fees from Merck and Co. (advisory board on antifungals in Canada), has a pending research grant from Pfizer Canada Inc. and has received payment from Pfizer Canada Inc. (symposium moderator). Michel Laverdière has received grants from Pfizer Canada Inc. and personal fees from Pfizer Canada, Merck Canada, and CME Solutions Canada. No other competing interests declared.

Funding: This study was supported by fellowship grants from the Université de Montréal and Hôpital Maisonneuve-Rosemont to Simon Dufresne.

Acknowledgements: The authors would like to acknowledge Stefania Chitu for her secretarial and data-retrieval activities.

Supplemental information: For reviewer comments and the original submission of this manuscript, please see www.cmajopen.ca/content $/ 2 / 2$ /E86/suppl/DC1 